\title{
GMR
}

\section{Acrocomia emensis (Arecaceae) genetic structure and diversity using SSR molecular markers}

\author{
D.S. Neiva ${ }^{1}$, A.F. Melo Júnior ${ }^{1}$, D.A. Oliveira ${ }^{1}$, V.A. Royo ${ }^{1}$, M.M. Brandão ${ }^{1}$ and \\ E.V. Menezes ${ }^{1}$ \\ 'Laboratório de Bioprospecção e Recursos Genéticos, \\ Departamento de Biologia Geral, Universidade Estadual de Montes Claros, \\ Campus Universitário Professor Darcy Ribeiro, Montes Claros, MG, Brasil \\ Corresponding author: E.V. Menezes \\ E-mail: menezes.elytania@gmail.com \\ Genet. Mol. Res. 15 (1): gmr.15017785 \\ Received October 6, 2015 \\ Accepted December 4, 2015 \\ Published March 24, 2016 \\ DOI http://dx.doi.org/10.4238/gmr.15017785
}

ABSTRACT. Acrocomia emensis, popularly known as the creeping tucum, belongs to the family Arecaceae, and is an oilseed specie of the Brazilian Savannah. The expansion of agricultural activity has rapidly destroyed its natural habitat, leading to a decrease in its population size. Genetic studies can be used to investigate the genetic variability, and may assist with the charting future conservation strategies. In this study the genetic diversity and structure of 150 individuals sampled in three locations in Minas Gerais were analysed, based on the transferability of six microsatellite markers, previously developed for $A$. aculeata. The results indicate that the populations studied have low levels of genetic variability $\left(H_{0}=0.148\right)$ and high, positive and significant inbreeding coefficient, indicating an excess of homozygotes. The average heterozygosity within the population $\left(H_{\mathrm{s}}=\right.$ 0.700 ) accounted for $95.03 \%$ of the total genetic diversity, indicating that there is greater variability within population than between them, consistent with low genetic differentiation between population $\left(G_{\mathrm{ST}}=0.046\right)$. Bayesian analysis identified three distinct groups; however, populations shared 
large numbers of alleles, which can be explained by the reduced distance between populations. These results reveal the need to implement genetic conservation programs for the maintenance of this species and to prioritize population from Bonito and Brasília, which showed the lowest values of genetic diversity.

Key words: Transferability; Microsatellites; Genetic variability

\section{INTRODUCTION}

The uncontrolled exploitation of natural resources presents a major challenge for the development of efficient strategies for population genetic conservation. Habitat loss and fragmentation are important factors that can alter population dynamics, genetic variability, and can lead to decreased fitness of the species (Hedrick and Miller 1992; Young et al., 1996). Some studies have discussed the effects of fragmentation on natural populations of tree species (Fuchs et al., 2003; Kramer et al., 2008). However, few studies have been performed on populations of the Brazilian Savannah, which are threatened by increasing human encroachment and development in this biome.

Acrocomia emensis (Toledo) Lorenzi (Arecaceae), popularly known as the creeping tucum, is an undergrowth, terrestrial, solitary, and espinescent palm. This species is characteristic of the lato sensu Cerrado and occurs in the states of Goiás, Mato Grosso do Sul, Minas Gerais, São Paulo, and Paraná (Leitman et al., 2012). Little is known about its economic potential; however, species from the same family as macaúba (Acrocomia aculeata) and buriti (Mauritia flexuosa) have gained importance in the energy (biodiesel), cosmetic, and food industries (Abreu et al., 2012). The accelerated destruction of the natural habitat of $A$. emensis, and the fact that it is not being cultivated, led Intituto Brasileiro do Meio Ambiente to consider this palm as a species at risk of extinction (Lorenzi, 2010). Thus, the study of population genetics becomes an essential tool in investigations of genetic diversity, so that such knowledge may be used in favor of the conservation and sustainable use of the species (Nei, 1987).

In this context, the use of molecular markers has aided the study of population genetics, making it possible to characterize the genetic structure between and within populations. Of these markers, simple sequence repeats (SSRs), or microsatellites, have been used to analyze the genetic diversity of vegetal species (Blair et al., 2007) as they are very informative due to their high level of polymorphism, codominant inheritance, and good reproducibility (Loridon et al., 2005). Furthermore, the transferability of these loci between closely related species reduces the cost of primer development, thus opening new perspectives for the development of population genetic studies. A high transfer rate has been reported for different plant species (Kriedt et al., 2011; Cota et al., 2012). Therefore, the purpose of this study was to genetically characterize a natural population of $A$. emensis using SSR markers and to investigate the transferability of primers developed for $A$. aculeata, in order to obtain estimates of genetic diversity and propose strategies for the genetic conservation of this species.

\section{MATERIAL AND METHODS}

\section{Study site and sampling}

Samples from three populations of $A$. emensis were collected in the north of Minas 
Gerais, within the Cerrado biome. In each population, 50 individuals were randomly collected and georeferenced using GPS. Young leaves from each plant were collected (Table 1), packed in plastic bags containing silica gel, and transported to the Bioprospecting and Genetic Resources Laboratory, located at Universidade Estadual de Montes Claros.

Table 1. Acrocomia emensis populations sampled in the North of Minas Gerais.

\begin{tabular}{l|l|c|c}
\hline Population & Codes & N & Coordinates (UTM) \\
\hline Bonito de Minas & BOM & 50 & $23 \mathrm{~K} \mathrm{5086508315987}$ \\
\hline Brasília de Minas & BRA & 50 & 23 K 5694148206247 \\
\hline Nova Esperança & NOV & 50 & 23 K 6008998169206 \\
\hline Total & & 150 & \\
\hline
\end{tabular}

$\mathrm{N}=$ number of individuals.

\section{DNA extraction}

We used 150-200 mg crushed leaves for DNA extraction, according to the methodology proposed by Doyle and Doyle (1990) and modified by Faleiro et al. (2003). The integrity of the extracted DNA was verified by electrophoresis on $1 \%$ agarose gel.

\section{Primer selection and transferability}

DNA amplification was performed using $3 \mu \mathrm{L}$ DNA extracted from the samples. SSR primer optimization was performed on thermocyclers (Veriti 96-Well Thermocycler Applied Biosystems). Primers and PCR conditions followed those described by Nucci et al. (2008), after the transferability of primers designed for $A$. aculeata and $A$. emensis was tested (Table 2).

\section{Table 2. Primer sequences.}

\begin{tabular}{l|l}
\hline Primer name & Sequence $\left(5^{\prime}-3^{\prime}\right)$ \\
\hline Aacu 10 & F: TGCCACATAGAGTGCTTGCT \\
& R: CTACCACATCCCCGTGAGTT \\
\hline Aacu 12 & F: GAATGTGCGTGCTCAAAATG \\
& R: AATGCCAAGTGACCAAGTCC \\
\hline Aacu 18 & F: TCCACCTTTAATGGGAGTGC \\
& R: TAAACAGCGCCAGGTCTTCT \\
\hline Aacu 26 & F: ACTTGCAGCCCCATATTCAG \\
& R: CAGGAACAGAGGCAAGTTC \\
\hline Aacu 30 & F: TGTGGAAGAAACAGGTCCC \\
\hline Aacu 35 & R: TCGCCTTGAGAAATATGGC \\
\hline Aacu 07 & F: AGAAGCCGATTCCTAATTG \\
& R: TGTGATTTTCTTACGCGTGC \\
\hline & F: TCGAAGGCCCTCCAATACT \\
& R: AAATAAGGGGACCCTCCAA \\
\hline
\end{tabular}

In total, seven pairs of primers were tested and the sizes of the amplified fragments were determined by comparison with the size standard DNA Liz 600 (Applied Biosystem) in an automatic sequencer DNA ABI 3500 (Applied Biosystems). The chromatograms produced were analyzed by the Gene Mapper v. 4.1 software (Applied Biosystems).

\section{Statistical analysis}

The level of genetic variation within populations was qualified by the number of alleles per 
locus $(A)$, observed heterozygosity $\left(H_{0}\right)$, expected heterozygosity $\left(H_{E}\right)$ over the Hardy-Weinberg equilibrium, Nei's genetic distance (1978), and Wright fixation index (f), which were estimated using the software Genetic Data Analysis (GDA) 1.1 (Lewis and Zaykin, 2001). Hardy-Weinberg equilibrium and linkage disequilibrium of pairs of loci were tested using the software FSTAT 2.9.3.2 with Bonferroni correction (Goudet, 2002). The genetic structure was estimated using Weir and Cockerham co-ancestrality coefficients (1984). The coefficients were estimated from the individual allele frequency variance using the FSTAT 2.9.3.2 software (Goudet, 2002).

The genetic variability structure of $A$. emensis populations was analyzed using Bayesian analysis implemented by the Structure software (Pritchard et al., 2000). Based on the genetic differentiation between populations, a dendrogram was built using the unweighted pair-group method with arithmetic averages (UPGMA) method using the NTSYS software, version 2.11 (Rohlf, 2000) from the genetic identity matrix, calculated according to the method described by Nei (1978). The Mantel test was used to test for possible correlations. These analyses were performed using the GenAIEx 6.1 software (Peakall and Smouse, 2006).

The kinship coefficient (fine scale genetic structure) was estimated using the Spagedi software version 1.2 (Hardy and Vekemans, 2002), considering a null inbreeding coefficient. The magnitude of the fine-scale genetic structure was measured using the Sp statistic (Vekemans and Hardy, 2004), using the formula: Sp = - bF / (1 - F1).

\section{RESULTS}

\section{Transferability of primers}

Seven SSR primers developed for $A$. aculeata were tested, and six generated polymorphic products from $A$. emensis samples. Most of the primers in this study required adjustments (reduction) in the annealing temperature, except for primer Aacu 12 (Table 3). Ninety-two alleles were detected in six microsatellite loci in the three sample sets.

Table 3. SSR primers used for amplifications of Acrocomia emensis.

\begin{tabular}{l|c|c|c}
\hline Loci & Repetitions & Ta $\left({ }^{\circ} \mathrm{C}\right)($ Nucci et al., 2008) & Ta $\left({ }^{\circ} \mathrm{C}\right)$ \\
\hline Aacu 10 & $(\mathrm{AG})_{16}$ & 56 & 52.5 \\
\hline Aacu 12 & $\left.(\mathrm{TC})_{20}\right)_{17}$ & 56 & 56 \\
\hline Aacu 18 & $(\mathrm{TG})_{13}$ & 56 & 52 \\
\hline Aacu 26 & $(\mathrm{AC})_{13}$ & 56 \\
\hline Aacu 30 & $(\mathrm{CA})_{18}$ & 56 & 47 \\
\hline Aacu 35 & $(\mathrm{TG})_{20}$ & 52 & 45 \\
\hline
\end{tabular}

$\mathrm{Ta}=$ Annealing temperature for $A$. aculeata primers.

\section{Genetic diversity}

The average $A$ had a homogeneous distribution among populations; however, this value slightly decreased in the population from Nova Esperança. The $H_{\mathrm{o}}$ was lower than the $H_{E}$ in populations from Bonito in Minas and Brasília de Minas, and was higher in the population from Nova Esperança (Montes Claros). The average $H_{\mathrm{E}}$ and $H_{\mathrm{O}}$ values were 0.695 and 0.148 respectively (Table 4). 
Table 4. Genetic diversity parameters of five Acrocomia emensis populations based on six microsatellite loci.

\begin{tabular}{l|c|c|c|c}
\hline Population & $H_{\mathrm{E}}$ & $H_{0}$ & $f$ & $A$ \\
\hline Bonito & 0.656 & 0.128 & $0.806^{*}$ & 10.33 \\
\hline Brasília & 0.753 & 0.223 & $0.705^{*}$ & 10.50 \\
\hline Nova & 0.675 & 0.916 & $0.865^{*}$ & 9.00 \\
\hline Average & 0.695 & 0.148 & $0.789^{*}$ & 9.94 \\
\hline
\end{tabular}

$f$ values followed by an asterisk are significant; $\mathrm{P}=0.003 . H_{\mathrm{E}}=$ expected heterozygosity; $H_{\mathrm{O}}=$ observed heterozygosity; $f=$ inbreeding coefficient; $A=$ average number of alleles per population.

The average $H_{0}$ for the $A$. emensis population analyzed was lower than expected, which revealed more homozygotes than were predicted under Hardy-Weinberg equilibrium. The excess of homozygotes is evidenced by the positive and significant values of the fixation index $(f)$ in the population with a mean value of 0.789 .

\section{Genetic structure}

Table 5 shows the genetic structure of $A$. emensis populations. The $H_{\mathrm{t}}$, which is essentially $H_{\mathrm{E}}$, was 0.734 ; and the $G_{\mathrm{ST}}$ was 0.046 . On the other hand, the average heterozygosity within the population $\left(H_{\mathrm{s}}=0.700\right)$ was responsible for $95.03 \%$ of the total genetic diversity, indicating the existence of greater variability within the population than between populations.

Table 5. Genetic structure of Acrocomia emensis populations in fragments and corridors.

\begin{tabular}{l|c|c|c}
\hline & $H_{\mathrm{t}}$ & $H_{\mathrm{s}}$ & $\mathrm{G}_{\mathrm{ST}}$ \\
\hline Average & 0.734 & 0.700 & 0.046 \\
\hline Standard deviation & 0.196 & 0.191 & - \\
\hline
\end{tabular}

$H_{\mathrm{t}}=$ total genetic heterozygosity; $H_{\mathrm{s}}=$ average heterozygosity within the population, and $G_{\mathrm{ST}}=$ population differentiation coefficient.

According to Wright (1978), $G_{\mathrm{ST}}$ values of 0.00 to 0.05 indicate low genetic differentiation, 0.05 to 0.15 indicate medium genetic differentiation, and 0.15 to 0.25 indicate high genetic differentiation. In the present study, low genetic divergence was observed among the population that is, the populations were similar.

Table 6 shows values obtained for the F statistic, proposed by Wright (1951), which uses inbreeding coefficient for describing the division of the genetic variability within and among populations, variability intra and inter population. All loci were significant and positive for $F_{\mathrm{IT}}$ and $F_{\mathrm{IS}}$, and the locus Aacu 30 had the highest value for both. $F_{\mathrm{ST}}$ had the highest value for all loci. The $R_{\mathrm{ST}}$ was negative but significant values were observed for the Aacu18 and Aacu12 loci. Differentiation among the population was verified by the index values $F_{\mathrm{ST}}$ and $R_{\mathrm{ST}}$, which were significant for all loci, with an average of 0.069 and 0.032 , respectively.

The average values obtained for these indices show that the majority of genetic diversity is within the population $\left(F_{\mathrm{IS}}=0.784\right)$, although there is moderate variation between populations $\left(F_{\mathrm{ST}}=0.069\right)$.

Bayesian analysis revealed the presence of three distinct groups $(k=3)$ Figure 1 represents the contribution of genotypes to each population. Therefore, all populations were observed to share a large number of alleles, which is likely due to the small geographic distance among them (Table 7). Of note, the BOM and BRA populations share the highest amount of alleles. In the dendrogram (Figure 2) obtained from the genetic identity matrix values (Nei, 1978), the formation of two groups can be observed: group I with population NOV, and group II with populations BOM and BRA. 
Table 6. $F_{\mathrm{IS}}$; inbreeding coefficient, $F_{\mathrm{IT}}$; total inbreeding coefficient $F_{\mathrm{ST}}$; fixation index, $R_{\mathrm{ST}}$; population genetic differentiation based on allele size.

\begin{tabular}{l|l|l|l|l}
\hline Locus & FiT & FST & Fis & RsT \\
\hline Aacu18 & $0.965^{*}$ & $0.164^{*}$ & $0.959^{*}$ & $-0.015^{*}$ \\
\hline Aacu12 & $0.631^{*}$ & $0.079^{*}$ & $0.599^{*}$ & $-0.001^{*}$ \\
\hline Aacu10 & $0.591^{*}$ & $0.043^{*}$ & $0.573^{*}$ & $0.023^{*}$ \\
\hline Aacu35 & $0.726^{*}$ & $0.021^{*}$ & $0.720^{*}$ & $0.019^{*}$ \\
\hline Aacu26 & $0.879^{*}$ & $0.023^{*}$ & $0.876^{*}$ & $0.040^{*}$ \\
\hline Aacu30 & $0.983^{*}$ & $0.066^{*}$ & $0.982^{*}$ & $0.146^{*}$ \\
\hline All loci & $0.799^{*}$ & $0.069^{*}$ & $0.784^{*}$ & $0.0382^{*}$ \\
\hline
\end{tabular}

${ }^{*} \mathrm{P}=0.001$, significant values.

Table 7. Geographic distance (in $\mathrm{km}$ ) (superior diagonal) among the Acrocomia emensis population, Nei genetic distance (1978) (lower diagonal).

\begin{tabular}{l|c|c|c}
\hline & BOM & BRA & NOV \\
\hline BOM & ${ }^{* \star *}$ & 123 & 174 \\
\hline BRA & 0.145 & ${ }^{* \star *}$ & 52 \\
\hline NOV & 0.215 & 0.236 & ${ }^{* * *}$ \\
\hline
\end{tabular}

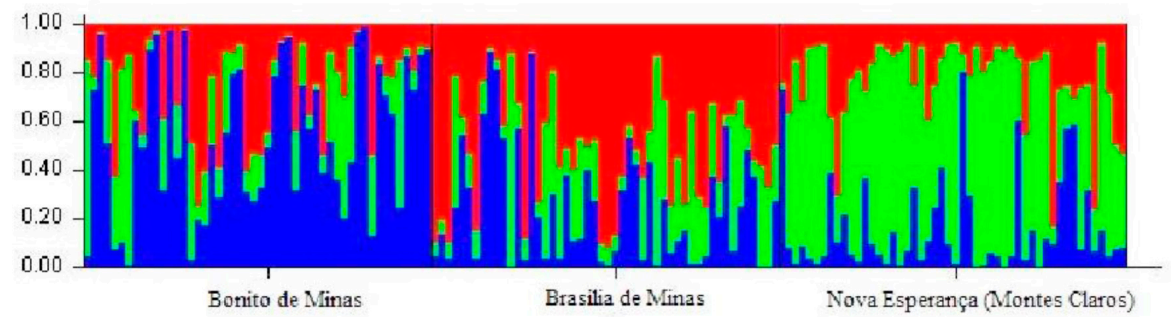

Figure 1. Distribution of 150 individuals from Acrocomia emensis across groups according to the STRUCTURE analysis $(k=3)$, based on microsatellite markers.

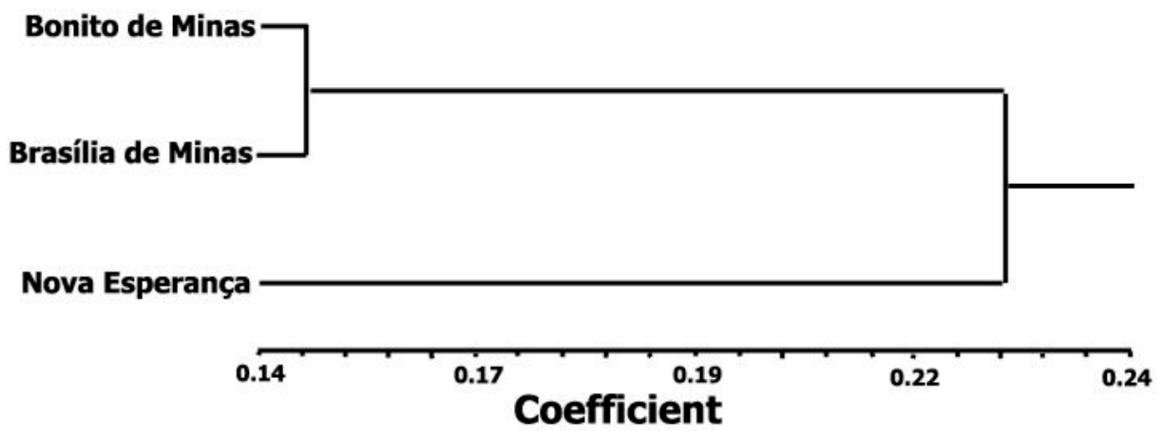

Figure 2. Unweighted pair-group method with arithmetic averages (UPGMA) dendogram of the sampled Acrocomia emensis population, calculated according to Nei's genetic identity (Nei, 1978). 


\section{Fine-scale genetic structure}

Correlograms of the studied $A$. emensis populations reveal a random genotype distribution, with a lack of significant genetic structure in the population from Brasília de Minas and Bonito de Minas and the presence of significant genetic structure in the population from Nova Esperança (Figure 3 and Table 8; $\mathrm{P}>0.05$ ).
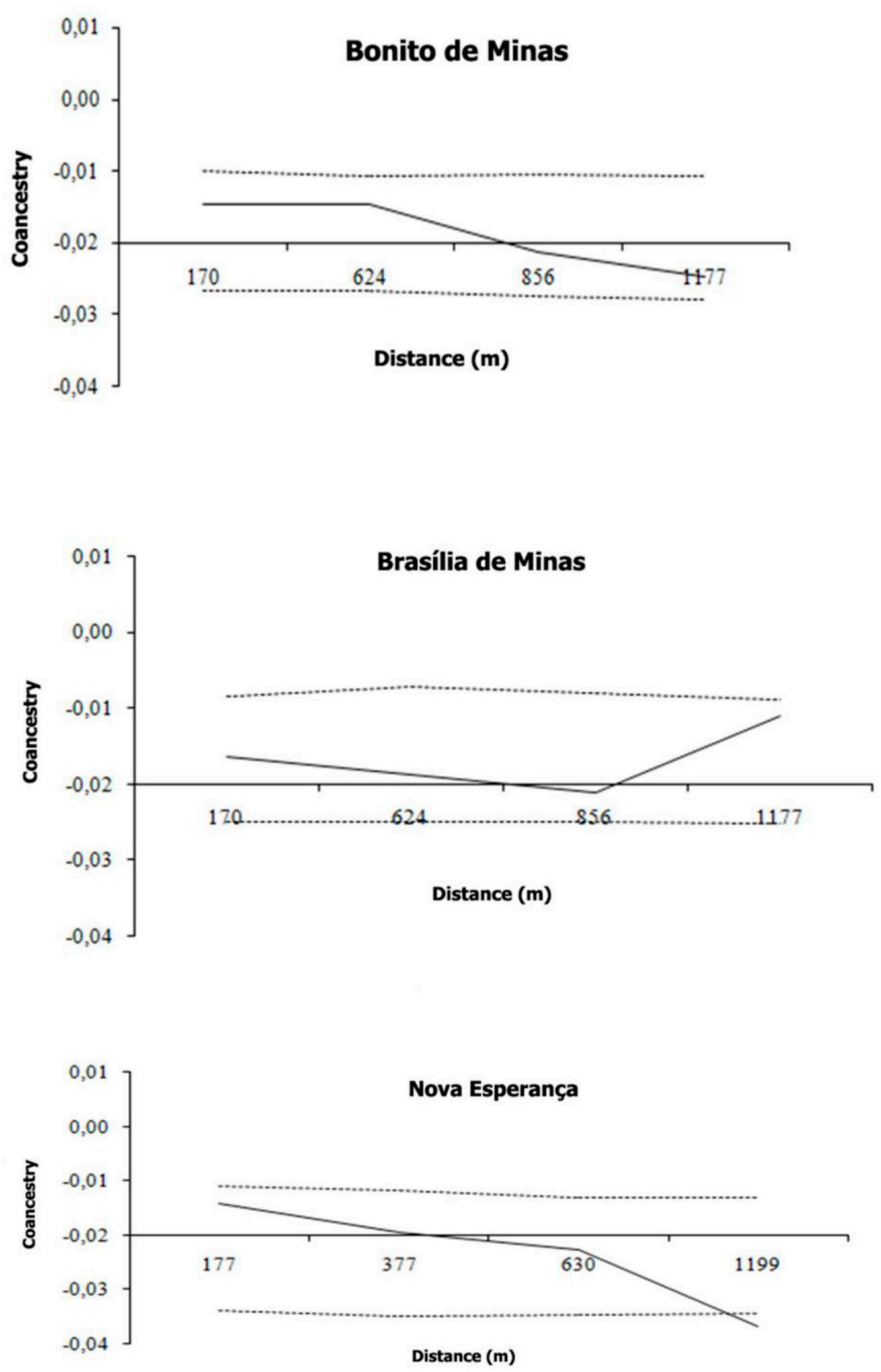

Figure 3. Co-ancestry coefficient correlogram (kinship), by distance class, for the Acrocomia emensis natural populations. Confidence interval at $95 \%$ likelihood are shown. 
Table 8. Acrocomia emensis fine scale structure characterization in the three population, including the kinship coefficient $\left(F_{i j}\right)$ for each population for the first distance class, the co-ancestry coefficient regression curve Blog, $S p$ statistics and significance value $(P)$.

\begin{tabular}{l|c|c|c|c}
\hline Population & $F_{\text {ij }}$ & Blog & $S p$ & $P$ \\
\hline BOM & -0.0153 & 0.0003737 & -0.0004 & 0.8162 \\
\hline BRA & -0.0165 & 0.001787 & -0.0018 & 0.2527 \\
\hline NOV & -0.0131 & -0.0016 & 0.00158 & 0.2927 \\
\hline Average & -0.015 & 0.000187 & -0.0002 & 0.45387 \\
\hline
\end{tabular}

\section{DISCUSSION}

Transferability of microsatellite primers for species within the same genus has been reported previously, Grattapaglia (2007) noted that transferability between species of the same genus is a desirable characteristic of SSR markers. Similar values of genetic diversity were reported for other savannah species, such as Jatropha curcas $L$. $\left(H_{\mathrm{O}}=0.53\right.$ and $H_{\mathrm{E}}=0.66$, Bressan et al., 2012), and Anacardium humile $\left(H_{\mathrm{O}}=0.463\right.$ and $H_{\mathrm{E}}=0.696$, Cota et al., 2012). Nucci et al. (2008) used SSR primers in nine $A$. aculeata, populations and found an $f$ value of 0.359 . Both populations analyzed are located within fragmented areas. Deforestation for illegal charcoal production occurs in Nova Esperança, and in Brasília de Minas and Bonito de Minas, the savannah is cleared to plant eucalyptus and pasture, respectively, accounting for the reduced size of the $A$. emensis population.

Fragmentation has several implications for the landscape structure, such as an increase of woodlands and greater isolation (Fahrig 2003), in addition to the possible loss of genetic variability due to a reduction of the effective population size (Sork and Smouse, 2006). In the case of habitat fragmentation, when gene flow was restricted, higher levels of inbreeding were observed in Euterpe edulis (Conte et al., 2006) and Myrciaria floribunda (Franceschinelli et al., 2007). The low number of heterozygotes and the high fixation index can be attributed to genetic drift by the bottleneck effect, or to a founder effect during settlement of the area, as this region was colonized by Amerindians who kept livestock, leading to the deforestation of large areas for pasture production (Sano et al., 2010). The population was founded by a few individuals who took part in inbreeding, which is evidenced by the increased fixation rate (Oliveira et al., 2006). Analysis of Hymenaea stigonocarpa using microsatellites markers revealed high levels of inbreeding within the study population, which in addition to the reduced number of individuals, may result from a strong founder effect (Defavari et al., 2009).

However, the population in Nova Esperança (Montes Claros) has increased heterozygosity, even when present within a fragmented environment. This is probably due to the area where $A$. emensis is located being larger in comparison to the others, or because the individuals were already present in the area before the disturbance. Thus, genetic drift may not have affected the rate of heterozygosity in this population, since the intensity of the effect is inversely proportional to the population size.

Introducing immigrants could be a plausible option, since the fragmentation may affect the remaining $A$. emensis population considering the values of heterozygosity, especially in a smaller population, which would theoretically be subject to faster loss of genetic variability due to drift (Wright, 1969).

The result of this study was similar to that obtained by Conte et al. (2006), who analyzed the genetic diversity of $E$. edulis in different developmental stages and found a $G_{\mathrm{ST}}$ value of 0.028 for adult individuals.

The $F_{\text {IS }}$ is the allele fixation index that occurs within the population, or measure inbreeding within the populations. The $F_{\mathrm{ST}}$ is the level of genetic differentiation between the populations, or 
measuring the degree of isolation between populations. The $F_{\mathrm{IT}}$ index shows the average reduction in heterozygosity of an individual compared to the whole population and the $R_{\mathrm{ST}}$ index is analogous to the $F_{\mathrm{ST}}$, or the genetic differentiation of the population based on the size of the microsatellite allele.

Studies performed in Caesalpinia echinata revealed an average inbreeding coefficient $\left(F_{\text {IS }}\right)$ of 0.305 , with the highest value being 0.788 , revealing that most of the genetic diversity occurs within the population (Oliveira et al., 2006).

It is possible that genetic diversity was maintained within and between populations due to historic events, and also due to recent evolutionary processes (Lee et al., 2002). Thus, considering the lack of information on the evolutionary and ecological history of $A$. emensis, explanations for the levels of genetic differentiation and standards found within and between the populations were inferred. Nevertheless, the populations from Brasília de Minas and Bonito de Minas are assumed to be a single population, which was founded by a small group of individuals; however, the geographic barrier between them, the São Francisco River, may have caused the division of this population.

The average genetic distance among population of $A$. emensis was 0.198 (Table 7), this was lower between populations from Brasília de Minas and Bonito de Minas (0.145) and higher between populations from Brasília de Minas and Nova Esperança (Montes Claros) (0.236), even though they are closer geographically. The population from Nova Esperança has the highest values for genetic distance, even though it is not geographically distant from the others; therefore, it is possible to conclude that these individuals may be isolated from the remaining population. The Mantel test did not show any significant correlation among the estimated geographic and genetic distances $(r=0.096 ; P=0.540)$, with the value being low, but positive for the $A$. emensis population.

Several evolutionary and ecological processes, such as environmental heterogeneity, limited dispersion of seeds and pollen, local genetic drift, inbreeding, and selection may affect the spatial distribution patterns of a population favoring one or different genotypes (Loveless and Hamrick, 1988). Thus, information on fine scale genetic structure is important for the management and conservation of forest genetic resources, and to assess and explore the impact of fragmentation (Bittencourt and Sebbenn, 2008)

The lack of significant fine scale genetic structure in the populations from Brasilia de Minas and Bonito de Minas indicates that there is random genotype distribution. It is likely that the pattern observed for these populations resulted from the large distance between sampled individuals when compared to the population from Nova Esperança. Future study may conduct sampling at smaller distances to verify whether the lack of structure is actually due to the distance between individuals or to the range of pollen or seed dispersion.

The significant spatial genetic structure (SGS) of the individuals from Nova Esperança in the last distance class indicates individual groupings, which are probably related and may be a consequence of the intense harvesting in that area, in addition to the history of anthropic disturbance, since vegetation in this area was explored for charcoal production. Overall, in smaller sized populations, the number of homozygous individuals tends to increase due to self-pollination, as well as inbreeding among closely related individuals due to the short dispersion distances of pollen and seeds (Loveless and Hamrick, 1984). Thus, for this population, understanding the genetic structure is of fundamental importance for the establishment of sampling strategies, aiming at in situ conservation. However, conservation strategies may not be performed based only on results of the fine scale genetic structure. It is also important to consider knowledge on the levels of diversity within and among populations, which provide a historical perspective of evolutionary changes that characterize a species, allowing prediction of the behavior of populations when subjected to future events of natural and artificial origin (Wallace, 2002). 
In conclusion, the transferability of microsatellite markers for $A$. emensis was successfully confirmed. The information obtained in this study shows that these transferred markers are a robust tool for the genetic analysis of $A$. emensis populations. Low levels of genetic diversity were found within the studied population, with diversity mainly distributed within populations. This shows that these $A$. emensis populations have potential for genetic conservation. The data obtained here are important for the monitoring of the current status of $A$. emensis species in the north of Minas Gerais, in addition to providing necessary information to establish conservation strategies and species improvement programs.

\section{Conflicts of interest}

The authors declare no conflict of interest.

\section{ACKNOWLEDGMENTS}

The authors thank the PETROBRAS for the fellowships (PFRH - PETROBRAS Program); Unimontes and State Forest Institute (IEF-MG) for logistics support.

\section{REFERENCES}

Abreu AG, Priolli RHG, Azevedo-Filho JÁ, Nucci SM, et al. (2012). The genetic structure and mating system of Acrocomia aculeata (Arecaceae). Genet. Mol. Biol. 35: 119-121.http://dx.doi.org/10.1590/S1415-47572012005000002

Bittencourt JM and Sebbenn AM (2008). Pollen movement in a continuous forest of Araucaria angustifolia, inferred from paternity and TWOGENER analysis. Conserv. Genet. 9: 855-868. http://dx.doi.org/10.1007/s10592-007-9411-2

Blair MW, Díaz JM, Hidalgo R, Díaz LM, et al. (2007). Microsatellite characterization of Andean races of common bean (Phaseolus vulgaris L.). Theor. Appl. Genet. 116: 29-43.http://dx.doi.org/10.1007/s00122-007-0644-8

Bressan E de A, Scotton DC, Ferreira RR, Jorge EC, et al. (2012). Development of microsatellite primers for Jatropha curcas (Euphorbiaceae) and transferability to congeners. Am. J. Bot. 99: e237-e239.http://dx.doi.org/10.3732/ajb.1100532

Conte R, Reis MS and Vencosky R (2006). Effects of management on the genetic structure of Euterpe edulis Mart. population based on microsatellites. Sci. Flor. 72: 81-88.

Cota LG, Moreira PA, Menezes EV, Gomes AS, et al. (2012). Transferability and characterization of simple sequence repeat markers from Anacardium occidentale to A. humile (Anacardiaceae). Genet. Mol. Res. 11: 4609-4616.http://dx.doi. org/10.4238/2012. October.17.7

Defavari GR, Tarazi R, Moreno MA, Ferraz EM, et al. (2009). Spatial genetic structure of Hymenaea stigonocarpa Mart. Ex Hayne in the Ecological Station of Itirapina, SP. Sci. Forum 37: 89-98.

Doyle JJ and Doyle JL (1990). Isolation of plant DNA from fresh tissue. Focus 12: 13-15.

Fahrig L (2003). Effects of habitat fragmentation on biodiversity. Annu. Rev. Ecol. Syst. 34: 487-515. http://dx.doi.org/10.1146/ annurev.ecolsys.34.011802.132419

Faleiro FG, Araújo IS, Bahia RCS, Santos RF, et al. (2003). Otimização da extração e amplificação de DNA de Theobroma cacao L. visando obtenção de marcadores RAPD. Agrotrópica 14: 31-34.

Franceschinelli EV, Vasconcelos GMP, Landau EC, Ono KY, et al. (2007). The genetic diversity of Myrciaria floribunda (Myrtaceae) in Atlantic Forest fragments of different sizes. J. Trop. Ecol. 23: 361-367. http://dx.doi.org/10.1017/ $\underline{\text { S0266467407004099 }}$

Fuchs EJ, Lobo JA and Quesada M (2003). Effects of forest fragmentation and flowering phenology on the reproductive success and mating patterns of the tropical dry forest tree, Pachira quinata. Conserv. Biol. 17: 149-157. http://dx.doi. org/10.1046/j.1523-1739.2003.01140.x

Goudet J (2002). FSTAT, A Program to Estimate and Test Gene Diversities and Fixation Indices (Version 2.9.3.2). Available at http://www.unil.ch/izea/softwares/fstat.html]. Accessed on October 15, 2014.

Grattapaglia D (2007). Aplicações operacionais de marcadores moleculares. In: Biotecnologia florestal (Borém A, eds.). Viçosa-MG:UFV. 175-200.

Hardy OJ and Vekemans X (2002). SPAGeDi: a versatile computer software to analyze spatial genetic structure at the individual or population levels. Mol. Ecol. Notes 2: 618-620. http://dx.doi.org/10.1046/j.1471-8286.2002.00305.x 
Hedrick PW and Miller PS (1992). Conservation genetics: techniques and fundamentals. J. Appl. Ecol. 2: 30-46. http://dx.doi. org/10.2307/1941887

Kramer AT, Ison JL, Ashley MV and Howe HF (2008). The paradox of forest fragmentation genetics. Conserv. Biol. 22: 878-885. http://dx.doi.org/10.1111/j.1523-1739.2008.00944.x

Kriedt RA, Ramos-Fregonezi AM, Beheregaray LB, Bonatto SL, et al. (2011). Isolation, characterization, and cross-amplification of microsatellite markers for the Petunia integrifolia (Solanaceae) complex. Am. J. Bot. 98: e277-e279. http://dx.doi. org/10.3732/ajb.1100178

Lee SL, Ng KK, Saw LG, Norwati A, et al. (2002). Population genetics of Intsia palembanica (Leguminosae) and genetic conservation of Virgin Jungle Reserves in Peninsular Malaysia. Am. J. Bot. 89: 447-459. http://dx.doi.org/10.3732/ ajb.89.3.447

Leitman P, Henderson A and Noblick L (2012). Arecaceae in Lista de Espécies da flora do Brasil, Jardim Botânico do Rio de Janeiro. Jardim Botânico do Rio de Janeiro. Available at: <http://floradobrasil.jbrj.gov.br/2012/>. Accessed on: January $11,2014$.

Lewis PO and Zaykin D (2001). Genetic Data Analysis: Computer Program for the Analysis of Allelic Data. Available at:[http:// hydrodictyon.eeb.uconn.edu/people/plewis/software.php].

Lorenzi H (2010). Flora Brasileira (Arecaceae). Nova Odessa: Instituto Plantarum.

Loridon K, McPhee K, Morin J, Dubreuil P, et al. (2005). Microsatellite marker polymorphism and mapping in pea (Pisum sativum L.). Theor. Appl. Genet. 111: 1022-1031. http://dx.doi.org/10.1007/s00122-005-0014-3

Loveless MD and Hamrick JL (1984). Ecological determinants of genetic structure in plant population. Annu. Rev. Ecol. Evol. Syst. 15: 65-95. http://dx.doi.org/10.1146/annurev.es.15.110184.000433

Loveless MD and Hamrick JL (1988). Genetic organization and evolutionary history in two North American species of Cirsium. Evolution 42: 254-265. http://dx.doi.org/10.2307/2409230

Nei M (1978). Estimation of average heterozygosity and genetic distance from a small number of individuals. Genetics 89 : 583-590.

Nei M (1987). Molecular evolutionary genetics. Columbia University, New York. 512.

Nucci SM, Azevedo-Filho JA, Colombo CA, Priolli RHG, et al. (2008). Development and characterization of microsatellites markers from the macaw. Mol. Ecol. Resour. 8: 224-226.http://dx.doi.org/10.1111/j.1471-8286.2007.01932.x

Oliveira CAM, da Silva EF, Molica SG, Ferreira RLC, et al. (2006). Diversity and genetic structure in populationof Caesalpinia echinata (Lam.) in the Ecological Station of Tapacurá, Pernambuco, Brazil. Sci. Forum 70: 77-83.

Peakall R and Smouse PE (2006). GENALEX 6: genetic analysis in Excel. Population genetic software for teaching and research. Mol. Ecol. Notes 6: 288-295. http://dx.doi.org/10.1111/j.1471-8286.2005.01155.x

Pritchard JK, Stephens M and Donnelly P (2000). Inference of population structure using multilocus genotype data. Genetics 155: 945-959.

Rohlf FJ (2000). Numerical taxonomy and multivariate analysis system. Version 2.11. New York: Applied Biostatistics.

Sano EE, Rosa R, Brito JLS and Ferreira LG (2010). Land cover mapping of the tropical savanna region in Brazil. Environ. Monit. Assess. 166: 113-124.http://dx.doi.org/10.1007/s10661-009-0988-4

Sork VL and Smouse PE (2006). Genetic analysis of landscape connectivity in tree population. Landscape Ecol. 21: 821-836. http://dx.doi.org/10.1007/s10980-005-5415-9

Vekemans $X$ and Hardy OJ (2004). New insights from fine-scale spatial genetic structure analyses in plant populations. Mol. Ecol. 13: 921-935.http://dx.doi.org/10.1046/j.1365-294X.2004.02076.X

Wallace LE (2002). Examining the effects of fragmentation on genetic variation in Platanthera leucophaea (Orchidaceae): inferences from allozyme and random amplified polymorphic DNA markers. Plant Species Biol. 17: 37-49. http://dx.doi. org/10.1046/j.1442-1984.2002.00072.x

Weir BS and Cockerham CC (1984). Estimating F-statistics for the analysis of population structure. Evolution 38: 1358-1370. http://dx.doi.org/10.2307/2408641

Wright S (1951). The genetical structure of populations. Ann. Eu- genics 15: 323-354.

Wright S (1969). Evolution and genetics of population. Vol. 2. The theory of gene frequencies. University of Chicago Press, Chicago. 511.

Wright S (1978). Evolution and genetics of population. University of Chicago Press, Chicago.

Young A, Boyle T and Brown T (1996). The population genetic consequences of habitat fragmentation for plants. Trends Ecol. Evol. (Amst.) 11: 413-418.http://dx.doi.org/10.1016/0169-5347(96)10045-8 